\title{
METAFÍSICA Y CREACIÓN EN EL PENSAMIENTO DE NIETZSCHE
}

\author{
Ana Isabel Illanes*
}

\begin{abstract}
Nietzsche concibe a la metafísica como la historia de un error en el que ha incurrido el pensamiento occidental, y que pretende superar. Desde su concepción, estamos ante un pensamiento reduccionista que ha pretendido constituirse en teoría única de la realidad. La historia de la metafísica se encuentra dominada por la tendencia de expulsar, de negar realidad a la multiplicidad y al devenir a partir de principios absolutos, inmutables, no-sensibles, racionales, trascendentes, perfectos y buenos que hacen surgir la diferencia de rango no sólo ontológico, sino también moral entre el mundo sensible y el inteligible. Así Nietzsche denuncia que para los metafísicos: La muerte, el cambio, la vejez, así como la procreación y el crecimiento son para ellos objeciones, -incluso refutaciones. Lo que es no deviene; y lo que deviene no es... ${ }^{1}$

Pensamos que Nietzsche completa la crítica a la metafísica, no sólo porque supera la insuficiencia de la crítica kantiana que mantiene el mundo suprasensible en la moral, o por hacer a un lado la crítica del positivismo y su sumisión ante los hechos, por incompleta y poco creativa, sino porque su llamada inversión del platonismo, que debemos

* Departamento Académico de Estudios Generales, ITAM.

${ }^{1}$ F. Nietzsche, Crepúsculo de los ídolos, trad. de Andrés Sánchez Pascual, 1989, Madrid, Alianza, p. 45-6.
\end{abstract}


entender como un nuevo comienzo, postula un nuevo orden jerárquico, que de ninguna manera quiere que lo sensible (apoyado por positivismo) se convierta en lo verdadero y lo suprasensible represente simplemente lo falso, ya que con el pensamiento nietzscheano estamos ante la eliminación de los términos de esta relación metafísica: dejar de pensar y vivir al mundo sensible a partir del mundo suprasensible, dándole una nueva interpretación a lo terreno y al mismo cuerpo.

Esta nueva forma de concebir el mundo se hace patente en Zaratustra, quien pugna por una cabeza terrena como creadora del sentido de la tierra. Contrario al tiempo en el que se miraba con desprecio al cuerpo, hoy nos debemos preguntar: “¿Qué anuncia vuestro cuerpo de vuestra a alma?”, 2 ya que “con más honestidad y con más pureza habla el cuerpo sano, el cuerpo perfecto y rectangular: y habla del sentido de la tierra". ${ }^{3}$

La genealogía representa la instancia desde donde Nietzsche realiza la superación de la metafísica. Y cuando nos muestra a la metafísica desde su historia, en su aparición, en su surgimiento, como algo derivado, no originario, producto de un desarrollo, de un tipo de experiencia: nos descubre que los conceptos básicos de la metafísica, sus principios y leyes fundamentales consideradas como más universales y originarias no se encuentran alejadas de determinados estados corporales, necesidades fisiológicas heredadas de organismos inferiores pero olvidadas, tales como el sueño, el sufrimiento y el miedo. Así detrás de estos fenómenos fisiológicos que se encuentran en el trasfondo de las creaciones metafísicas no se encuentra el espíritu puro, ni la verdad absoluta, ni tampoco un Dios, sino un hombre que tiene necesidad de un género de ordenamiento, que ante el sufrimiento, el miedo al cambio, al devenir, postula un orden supraempírico que le posibilite manejar la realidad.

${ }^{2}$ Así habló Zaratustra, trad. de Andrés Sánchez Pascual, 1981, Madrid, Alianza, p. 35.

${ }^{3}$ Ibid., p. 59. 
El disfraz inconsciente de las necesidades fisiológicas bajo el manto de lo objetivo, del ideal, de la idea pura, va tan lejos, que nos asustaríamos, y yo me he preguntado muchas veces si, de una manera general, la filosofía no ha sido hasta el presente, sobre todo, una interpretación del cuerpo y 'un desconocimiento del cuerpo'. [...] En primera línea podemos poner siempre todas esas audaces locuras de la metafísica, sobre todo cuando se trata de la cuestión del 'valor' de la vida, como síntomas de constituciones físicas determinadas; y si tales afirmaciones; o tales negaciones; de la vida tienen, en su conjunto, la menor importancia desde el punto de vista científico, no por eso dejan de dar al historiador y al psicólogo preciosos indicios por ser síntomas del cuerpo, de su éxito o de su fracaso, de su plenitud, de su poder, de su soberanía en la historia, o bien de sus detenciones, de sus fatigas, de sus depauperaciones, de su presentimiento del fin, de su voluntad de fin. [...] En los filósofos todos, hasta el presente, no se ha tratado nunca de la 'verdad', sino de otras cosas, por ejemplo de salud, de porvenir, de poder, de vida...

En el pensamiento de Nietzsche, la metafísica lejos de ser desinteresada, esconde creencias y valores: una moral, una fe ligada a intereses vitales, a un tipo de vida. Por detrás de las construcciones metafísicas se encuentra un tipo de hombre que desestima lo sensible, la pluralidad y el movimiento, que manifiesta una rabia secreta, una venganza contra la vida, contra el cuerpo. El metafísico manifiesta síntomas de envejecimiento y cansancio, de incapacidad para imponer su voluntad de una manera creadora, que nuestro filósofo quiere revertir. De ahí que intente una nueva manera no-metafísica de entender al mundo y al hombre, que no parta de la idea de una realidad inmutable, meta-física

${ }^{4}$ La gaya ciencia, O.C., Prólogo, vol. III, trad. de Eduardo Ovejero Maury, 1967, Buenos Aires, Aguilar, p. 26-7. 


\section{ANA ISABEL ILLANES}

que subyazca a todo movimiento; ni del hombre postulado por la metafísica como una aeterna veritas, como elemento fijo y medida fija.

Su crítica a la metafísica que parte del cumplimiento de la muerte del Dios del cristianismo monoteísta, fundamento de este mundo suprasensible, nos enfrenta por una parte, a la pérdida de medidas, de parámetros absolutos, de fines ya dados, de fronteras establecidas: nos pone cara a cara con lo problemático de una existencia humana que ha perdido su sentido. Así en La gaya ciencia hace mención a la importancia de dicha pérdida y subraya el valor, la fuerza que necesitamos para aceptarla:

¿Dónde se ha ido Dios? [...] ¡Todos nosotros somos sus asesinos! Pero ¿cómo hemos podido obrar así? ¿Cómo hemos podido vaciar el mar? ¿Quién nos ha dado la esponja para borrar el horizonte? ¿Qué hemos hecho cuando hemos separado esta tierra de la cadena de su sol? ¿Adónde le conducen ahora sus movimientos? ¿Lejos de todos sus soles? ¿No caemos sin cesar? ¿Hacia adelante, hacia atrás, de lado, de todos lados? ¿Todavía hay un arriba y un abajo? ¿No erramos como a través de una nada infinita? El vacío ¿¿no nos persigue con su hálito? ¿No hace más frío? ¿No veis oscurecer cada vez más, cada vez más? [...] Lo que el mundo poseía de más sagrado y más poderoso ha perdido su sangre bajo nuestro cuchillo. ${ }^{5}$

Ante la pérdida de parámetros absolutos, Nietzsche postula una nueva creación simplemente humana que devuelve al hombre su verdadera dimensión temporal, corporal, múltiple y azarosa, y lo conduce hacia una auténtica disponibilidad para lo real, para lo terreno en su presencia multiforme. Podemos decir que la reflexión nietzscheana nos presenta una manera distinta de concebir la existencia, ya que una vez descartado el hombre empobrecido de la metafísica y su mundo verdadero, suprasensible, la realidad puede ser interpretada y vivida

${ }^{5}$ Ibid., (125), p.108-9. 
de múltiples maneras, se puede acceder al momento creativo, donde la aventura de múltiples experimentos puede ser posible y el enigma de la existencia está siempre presente.

Pues para el pensamiento genealógico, el llevar hasta sus últimas consecuencias la muerte del Dios monoteísta, el último fundamento de la metafísica, no significa la anulación de todo sentido, de todo pensar y quehacer humano. Más bien este pensamiento anuncia 'una historia más elevada'. Al reintroducir el devenir en todo lo que se había creído inmóvil, rehabilita al devenir: éste deja de ser interpretado, a la manera de la metafísica, como una carencia, como una falta, casi como un no-ser, para llegar a ser parte constitutiva de la creación.

Su genealogía nos muestra tanto al hombre como a sus facultades desde su historia, desde sus mutaciones, como resultado de múltiples cambios y transformaciones. Considera al mismo cuerpo como guía, ${ }^{6}$ y al hacerlo actualiza la historia desde otras instancias sin privilegiar al intelecto, a la conciencia. Contrario al logocentismo que ha marcado el pensamiento de Occidente, Nietzsche cambia los términos de la relación con el cuerpo, alma, razón, espíritu, que el pensamiento metafísico había mantenido. Desde su pensamiento, el cuerpo siendo pluralidad y lucha se convierte en 'una gran razón', en un creador. El que 'hace yo'. Todo esto en contra posición del espíritu que termina siendo la pequeña razón, el instrumento. Así nos dice: "Instrumento de tu cuerpo es también tu pequeña razón, hermano mío, a la que llamas 'espíritu', un pequeño instrumento y un pequeño juguete de tu gran razón... Tu cuerpo es tu gran razón: esa no dice yo, pero hace yo.”7

Para Nietzsche, la dimensión del cuerpo se ensancha, éste se vuelve el sí-mismo, que se encuentra detrás de los pensamientos y sentimientos; es un soberano poderoso, un sabio desconocido, ya que hay más

6 “Esencial: partir del cuerpo y utilizarlo como guía. Él es el fenómeno más rico que permite observaciones más claras. La creencia en el cuerpo está mejor fundamentada que la creencia en el espíritu.” La voluntad de dominio, O.C., op. cit., vol. IV, (531), p. 207. 
razón en el cuerpo que la mayor sabiduría. Lo que más quiere el símismo es crear por encima de sí mismo.

"El sí-mismo escucha siempre y busca siempre: compara, subyuga, conquista, destruye. Él domina y es también el dominador del yo. [...] El sí-mismo creador se creó para sí el apreciar y el despreciar, se creó para sí el placer y el dolor. El cuerpo creador se creó para sí el espíritu como una mano de su voluntad." 8

Esta nueva manera de concebir y entender la realidad acentúa el factor creativo. Y esto se puede percibir en su crítica tanto de la lógica como del lenguaje ligados al pensamiento metafísico. Por una parte, no sólo nos dice que la lógica no representa lo originario ni responde a una necesidad objetiva, sino que por detrás de ésta está una creación humana vinculada a necesidades subjetivas de encontrar 'casos idénticos', por razones de seguridad y de orden ante un mundo que nos parece caótico. Podemos decir que con la lógica estamos ante ficciones convencionales en sí ilógicas que encuentran identidades donde no las hay, que separa dualística y arbitrariamente lo que en realidad es continuo devenir; ante inferencias no justificadas, que resultan de nuestro modo humano de entender la realidad, ya que la lógica se determina desde instancias no-lógicas, previas a la conciencia y al lenguaje: se determina desde la vida, como producto, como invento, como una creación de los animales inteligentes en su lucha por la existencia. Ésta es una creación más en la historia del hombre, una especie de ‘segunda naturaleza' que ayuda a perpetuar su existencia.

La lógica está ligada a la condición y al supuesto de que hay casos idénticos. Taxativamente, para que pueda haber lógica, se debe convenir o fingir que esta condición y este supuesto se dan. Es decir: que la voluntad para la verdad lógica sólo puede realizarse después de haber admitido una falsificación fundamental de todos los hechos. De donde se deduce que aquí rige un instinto que es capaz de las dos cosas: primero de falsifica-

${ }^{7}$ Así habló Zaratustra, op. cit., p. 60.

${ }^{8}$ Ibid., p. 61. 
ción y luego de la realización de su punto de vista; la lógica no procede de la voluntad de verdad. ${ }^{9}$

Con esto, Nietzsche no descarta a la lógica, sino que la entiende de una manera no metafísica, la explica desde otra instancia: desde la voluntad de poder, pues para él en la lógica rige un instinto capaz de realizar su punto de vista, una fuerza ordenadora, simplificadora, falseadora: una actividad creadora.

Nietzsche reconoce, en la lógica y en cualquier tipo de pensamiento, la acción de un instinto 'creador' que ante lo desconocido, ante el peligro, ante la inquietud y la preocupación viene a eliminar esos estados penosos construyendo pensamientos tranquilizadores, aliviadores, liberadores con los que se puede vivir, pero que no tienen nada que ver con la verdad. Detrás de la lógica hay un deber, un imperativo no para el conocimiento de la verdad, sino para fijar y acomodar un mundo que nosotros debemos llamar verdadero. Cosa que nos sitúa más allá de la verdad, donde la no-verdad puede ser condición de vida. Desde esta óptica la verdad deja su lugar a la creencia, a una creencia 'superficial', que no se encuentra ligada a absolutos, que permite una visión diferente, perspectivista de la propia vida.

[...] el hombre no podría vivir si no admitiese las ficciones lógicas, si no midiese la realidad con la medida del mundo puramente inventado de lo incondicionado, idéntico-a-sí-mismo, si no falsease permanentemente el mundo mediante el número [y todo tipo de abstracciones] [...] renunciar a los juicios falsos sería renunciar a la vida, negar la vida. Admitir que la no-verdad es condición de la vida: esto significa desde luego, enfrentarse de modo peligroso a los sentimientos de valor habituales; y una filosofía que osa hacer esto se coloca, ya sólo con ello, más allá del bien y del mal. ${ }^{10}$

${ }^{9}$ La voluntad de dominio, op. cit., (511), p. 198. 
En el caso del lenguaje, Nietzsche reconoce un abismo entre realidad y lenguaje. El lenguaje -inventor y abogado de la 'identidad' de las cosas, de la 'substancia', de argumentación lógica, de la metafísicaen su formación no siguió un proceso lógico, sino un olvido arbitrario de las diferencias individuales; se equipararon cosas no iguales; se crearon 'identidades' hasta llegar a atribuirle al lenguaje un papel de representación de las cosas, olvidándose la relación arbitraria con dichas cosas. En el pensamiento del filósofo, el lenguaje entendido como instrumento para acceder a la esencia de las cosas sufre un desplazamiento por el lenguaje metafórico. Si Nietzsche desautoriza la función representativa y denotativa que la metafísica atribuye al lenguaje, es porque para él la fuente original del lenguaje y del conocimiento está en la posibilidad de crear imágenes; en esa actividad originaria, radical, innovadora y artística que tiene la mente humana de crear metáforas de cosas que no corresponden en absoluto a las esencias; en ese instinto inconsciente, constructor de metáforas, que está al servicio de la vida, al servicio de un orden, de un poder.

Desde esta óptica la formación de metáforas presupone un salto originario, un comportamiento estético que salva el abismo entre esferas completamente diferentes. Un salto que no está controlado por ninguna regla y para el que no hay ningún criterio de certeza. Podemos señalar que Nietzsche libera el instinto metafórico del ser humano para el juego creativo, cosa que produce una nueva relación con las cosas, ya que los instintos metafóricos proceden de una fuerza que arriesga, que salta de una cosa a otra y que es capaz de crear las mejores ficciones, pues las metáforas no deben entenderse como copias de un modelo, sino como imágenes producidas por la fantasía. Deben entenderse como metamorfosis, como transfiguración, como movimiento que nos coloca ante un crear infantil, inocente, cuya misión es fundar un sentido nuevo que vaya más allá del lenguaje conceptual: hacia la vida que sigue siendo inconceptualizable, completamente individualizada.

${ }^{10}$ Más allá del bien y del mal, (4), p. 24. 
Qué agradable es que existan palabras y sonidos: ¿palabras y sonidos no son acaso arcos iris y puentes ilusorios tendidos entre lo eternamente separado? [...] ¿No se le han regalado acaso a las cosas nombres y sonidos para que el hombre se reconforte en las cosas? Una hermosa necesidad es el hablar: al hablar el hombre baila sobre todas las cosas. ¡Qué agradables son todo hablar y todas las mentiras de los sonidos! Con sonidos baila nuestro amor con multicolores arcos iris. ${ }^{11}$

En oposición al conocimiento metafísico, Nietzsche acerca el conocimiento a la vida. Nos propone una nueva forma de conocimiento: el conocimiento interpretativo y perspectivista que desmitifica el valor dado al intelecto humano y que rehabilita al cuerpo al integrar como parte constitutiva del conocimiento a los valores, a los instintos a las pasiones, así como la pluralidad y el cambio que arrojan los datos de los sentidos, sin subsumirlos a la unidad, a la identidad, a la substancia. Establece nuevos ordenamientos entre instinto y razón que colocan como centro de gravedad al cuerpo.

El conocimiento perspectivista considera la pluralidad instalada en el cuerpo. Al mantener una diferencia radical entre los tipos de percepciones, y al no pretender llegar a una única percepción totalizadora tomada como completa, correcta y válida en un sentido absoluto, que pueda ser tenida como medida única y como fundamento último de la realidad, nos coloca ante la posibilidad de múltiples percepciones igualmente validas.

[...] la cuestión de cuál de las dos percepciones del mundo es la correcta carece totalmente de sentido, ya que para decidir sobre ello tendríamos que medir con la medida de la percepción correcta, es decir, con una media de la que no se dispone. Pero, por lo demás, la 'percepción correcta' -es decir, la expresión adecuada de un objeto en un sujeto-me parece un absurdo

${ }^{11}$ Así habló Zaratustra, p. 299. 
ANA ISABEL ILLANES

lleno de contradicciones, puesto que entre dos esferas absolutamente distintas, como lo son el sujeto y el objeto, no hay ninguna causalidad, ninguna exactitud, ninguna expresión, sino, a lo sumo, una conducta estética, quiero decir: un extrapolar alusivo, un traducir balbuciente a un lenguaje completamente extraño, para lo que, en todo caso, se necesita una esfera intermedia y una fuerza mediadora, libres ambas para poetizar e inventar. $^{12}$

El proponer el carácter perspectivista de nuestro conocimiento, no sólo nos ubica en un lugar nunca antes pensado, ante la posibilidad infinita e irrefutable de interpretaciones humanas, 'no divinas', donde los diferentes puntos de vista no pretenden ser complementarios, sino que al mostrarnos aspectos esencialmente distintos de modos de percibir, irreductibles los unos a los otros, nos coloca ante las múltiples posibilidades de lo corpóreo.

Tomando como guía las perpetuas mutaciones del cuerpo, desenmascara al concepto de yo, de sujeto entendido como algo estable que permanece en el cambio, así como su transposición de estabilidad a las creaciones metafísicas de ser, de sustancia y de 'cosa en sí'. En el lugar del yo, que encubre bajo el manto de unidad: pluralidad y complejidad; en lugar del sujeto metafísico, del sujeto como fundamento que observa el mundo, postula una pluralidad de almas mortales, ${ }^{13}$ de deseos y apetitos que construyen un mundo. Para nuestro filósofo, en la base de nuestro pensar, de nuestra ideación, de nuestra conciencia se encuentra una pluralidad de fuerzas en juego y lucha, donde se dan formas específicas de dominación marcadas por una constante transitoriedad, fugacidad y caducidad, mas no por la permanencia. Podemos decir que Nietzsche lleva hasta sus últimas consecuencias la elimi-

${ }^{12}$ F. Nietzsche, Sobre verdad y mentira en sentido extramoral, trad. de L. Valdés y Teresa Orduña, 1990, Madrid, Tecnos, p. 29-30.

${ }^{13}$ Estamos ante el cuerpo como pluralidad de almas mortales, como una estructura social de muchas almas. 
nación del sujeto metafísico para quedarse con un centro de interpretaciones, con un centro de fuerzas plurales siempre en movimiento, siempre haciéndose a sí mismo: de fuerzas orientadas según una jerarquía sin centro permanente. Así menciona:

[...] quizá sea lícito admitir una pluralidad de sujetos, cuyo juego y cuya lucha sean el fundamento de nuestra ideación y de nuestra conciencia. ¿Una especie de aristocracia de 'células’ en la cual esté el poder? ¿Algo así como ‘pares’ que están acostumbrados a gobernar juntos y sepan mandar? Mi hipótesis: el sujeto como pluralidad. ${ }^{14}$

Con el perspectivismo nietzscheano no se postula ni un positivismo que parta de la existencia inobjetable de los hechos, ni un subjetivismo de corte idealista que opere con un sujeto trascendental, sino un conocimiento como interpretación, carente de fundamentos, ya que no hay hechos sino interpretaciones, y detrás de toda interpretación hay otra interpretación. ${ }^{15}$ Desde esta óptica, en la experiencia del mundo sólo se leen los textos, textos que a su vez son interpretaciones de otros textos sin que se pueda llegar a un referente último que sea realidad, que sea inmediatez. Podemos decir que el pensamiento de Nietzsche se abre a una nueva dimensión creadora, donde el conocer se transforma en un interpretar, en un inventar un texto que no existe y que es necesario escribir, pero no como algo que esté ahí y que haya que encontrar y descubrir, sino como algo que hay que crear. Estamos ante un

[...] necesario perspectivismo en virtud del cual todo centro de fuerza -y no solamente el hombre-construye, partiendo de sí, todo el resto del mundo, o sea lo mide, lo palpa, lo forja según su propia fuerza. [...] Han olvidado introducir en el cálculo del 'verdadero ser' esta fuerza que pone una perspectiva [... . ${ }^{16}$

${ }^{14}$ La voluntad de dominio, op. cit., (489), p. 193-4.

${ }^{15}$ Véase ibid., (480), p.191.

${ }^{16}$ Ibid., (633), p. 242. 


\section{ANA ISABEL ILLANES}

Y desde esta óptica, nuestras interpretaciones no son ni verdaderas ni falsas, como pretende la metafísica, sino que son un síntoma de determinados estados fisiológicos, de un determinado nivel espiritual de juicios dominantes, donde la vida constituye una potencia interpretadora sin límites que posibilita la creación de múltiples sentidos. Con esto, el conocimiento perspectivista adquiere un rango nuevo, una nueva movilidad donde pueden coexistir pensamientos múltiples, heterogéneos y hasta contradictorios, pues este conocimiento, que se abre a la multiplicidad, escucha al cuerpo, a su caducidad, a su pluralidad que engloba elementos heterogéneos e intenta eliminar todas las supuestas 'unidades' de las cosas. Bajo esta visión, el mundo existe como un ser de relaciones cambiantes, siendo su ser esencialmente distinto, nuevo si es mirado desde diferentes puntos, desde diferentes perspectivas.

Con respecto a la voluntad de poder que Nietzsche identifica con la vida, no se debe entender desde ningún planteamiento teleológico. Para su comprensión, nuestro filósofo hace a un lado causas finales, leyes de la naturaleza, así como concepciones antropomórficas y moralizantes que conciben al mundo guiado por la mano de la Providencia. El tener metas, fines, intenciones y el mismo querer de esta voluntad, sólo lo entiende desde un tratar de devenir más fuerte, un querer crecer y querer los medios necesarios para ello. Por lo cual, la voluntad de poder no pretende una homogeneización, ni un conservarse (Spinoza), sino incrementar su poder, ya que no se le puede pedir a una fuerza que no se ejerza como tal.

La vida como la forma de ser conocida por nosotros es, específicamente, una voluntad de acumular fuerzas; todos los procesos de vida tienen aquí su palanca: nada quiere conservarse, todo debe ser sumado y acumulado. [...] el querer devenir más fuerte partiendo de cualquier centro de fuerza, es la única realidad: no conservación de sí mismos, sino voluntad de apropiarse, de adueñarse, de ser más, de hacerse más fuerte. ${ }^{17}$

${ }^{17}$ Ibid., (686), p. 263. 
La voluntad de poder tiene un papel en la creación, pues dicha voluntad es interpretadora, es creadora de interpretaciones, en ella es el poder quien quiere, crece, conquista, crea, y ante todo valora, sin que el poder sea una meta, un objetivo, un ideal. Desde esta óptica, el poder nunca es representado ni interpretado o valorado, pues él es lo que interpreta, lo que valora, lo que quiere y crea; siendo el poder en la voluntad algo inexpresable, móvil, variable, plástico. La voluntad interpreta a partir de ella misma, desde una inmanencia radical y su movilidad propia supera toda fetichización, toda definición metafísica de esencia, de sustancia, de deber ser, de verdad y valor absoluto.

Mis escritos afirman constantemente que el valor del mundo se encuentra en nuestra interpretación (que acaso en cualquier otro lugar son posibles otras interpretaciones distintas de las simplemente humanas); que las interpretaciones hasta ahora admitidas son evaluaciones perspectivas, en virtud de las cuales nos conservamos en la vida, o sea en la voluntad de poderío, en el aumento del poderío; que toda elevación del hombre lleva consigo la superación de interpretaciones más restringidas; que cada consecución de nueva fuerza y de extensión del poder abre nuestras perspectivas y significa creer en nuevos horizontes. El mundo que nos interesa es falso, esto es, no un hecho, sino una imaginación y un englobamiento de una escasa suma de observaciones; es fluido, como cosa que deviene como una falsedad que continuamente se desvía, que no se acerca nunca a la verdad, porque no hay 'verdad' ninguna. ${ }^{18}$

La voluntad de poder se encuentra referida a un tipo de jerarquía ajena a la metafísica, ya que no tiene su fundamento en realidades suprasensibles, absolutas e incondicionales, sino a niveles de fuerzas, donde el grado de resistencia (siempre variable, con medidas siempre móviles) determinan el nivel de la jerarquía. Y en este punto, la jerar-

${ }^{18}$ Ibid., (613), p. 235. 
quía -que Nietzsche defiende-le regresa al cuerpo la importancia que la metafísica le había negado. Nuestro filósofo crea un nuevo vínculo productivo entre el cuerpo y el pensamiento, una nueva voluntad que asimila la valoración positiva de esta corruptibilidad (caducidad, movimiento), donde el nexo que vincula las intensidades del cuerpo y las perspectivas del pensar nunca se presenta como estable.

La voluntad de poder no se puede entender desde categorías ontológico-metafísicas, ya que ésta no es un ser, no es un devenir, sino un pathos: es el hecho elemental, del cual resulta precisamente un devenir y un obrar. Es una forma primitiva de pasión creadora, configuradora de toda otra pasión, ${ }^{19}$ y el interpretar mismo, por parte de esta voluntad, no tiene existencia como 'ser' ni como un 'yo', sino como un proceso en devenir, como un afecto, pues quienes interpretan son nuestros afectos. Por otra parte, no se puede hablar de una voluntad de poder como ser, pues la voluntad de poder sólo nos da la apariencia de ser, mas no el ser. Estamos ante un devenir, que debido a la manifestación de determinadas fuerzas que muchas veces se asemejan a una teleología, aparenta, crea la ilusión de ser, pero sólo se le da el carácter de ser a través de una falsificación. Cosa que nos acerca a la falsificación como el carácter básico de la existencia, donde la 'verdad' significa querer hacer pensable todo ser, pero, en ningún caso, salir de la ficción creadora. Así Nietzsche nos dice: “El imprimir al devenir el carácter de ser es la más alta voluntad de poderío. Se realiza una doble falsificación: una que parte de los sentidos, y la otra del espíritu, para conservar un mundo del ser, de la duración, de la equivalencia, etcétera.”20

Esta voluntad de poder creadora, que se identifica con la vida, está ligada a una vida que experimenta, así como al juego y a la lucha, a fuerzas siempre desiguales que se resisten unas a otras y que no obedecen a un ordenamiento metafísico ya dado (absoluto, incondicionado, trascendente). En sus creaciones prevalece el 'enigma', la incógnita, el misterio, la falta de certeza que no admite esquemas prefijados.

${ }^{19}$ Véase ibid., (632), p. 242.

${ }^{20}$ Ibid., (614), p. 235. 
En cuanto a la idea de eterno retorno -que parte del supuesto de la existencia de fuerzas finitas y del tiempo considerado como eterno, y que como tal, lleva consigo la eterna repetición de todas las posibles combinaciones de las fuerzas- elimina el supuesto de la repetición eterna de un primer modelo ${ }^{21}$ tan cercano al pensamiento metafísico, así como la pretensión de una creación ex nihlo. El eterno retorno es contrario a las doctrinas que afirman una renovación eterna de las fuerzas, así como a la concepción moderna de progreso, y a la idea metafísica de eternidad situada en un más allá trasmundano. Mientras que lo eterno para la metafísica presupone la negación de lo perecedero, desde el eterno retorno, se redime lo perecedero, se eterniza, sin situar a la eternidad por detrás del tiempo, ya que deja de concebirse éste como tendencia que termina en un no-movimiento, en un no-tiempo, para pensar el tiempo como la dimensión propia de toda realidad.

El eterno retorno no manifiesta ni tendencia teleológica, ni objetivo ni metas trascendentes, ya que parte de un círculo cerrado, que no añade ni suprime nada, donde la inmanencia se asume hasta sus últimas consecuencias. Nos encontrarnos ante un mundo sin fin que crea y destruye eternamente, ante un mundo dionisíaco, enigmático, inocente; carente de interpretaciones teleológico-morales, que se encuentra más allá del bien y del mal, donde lo perecedero, que ya no se encuentra en función de lo imperecedero, está liberado de la interpretación metafísico-moral y es afirmado en su finitud. Desde el eterno retorno se asume la inocencia del devenir, y se nos invita a tomar el mundo tal como es, y no tal como debería ser, ya que desde el pensamiento nietzscheano:

Nosotros hemos inventado el concepto 'finalidad': en realidad falta la finalidad. [...] Se es necesario, se es un fragmento de la fatalidad, se forma parte del todo, se es en el todo, -no hay nada que pueda juzgar, medir, comparar, condenar nuestro ser,

${ }^{21}$ Véase Eugen Fink, La filosofía de Nietzsche, trad. de Andrés Sánchez Pascual, 1984, Madrid, Alianza, primeros capítulos. 
ANA ISABEL ILLANES

pues esto significará juzgar, medir, comparar, condenar el todo. [... ¡ Pero no hay nada fuera del todo! Que no se haga ya responsable a nadie, que no sea lícito atribuir el modo de ser a una causa prima, que el mundo no sea una unidad ni como sensorium ni como 'espíritu’, sólo esto es la gran liberación, -sólo con esto queda restablecida otra vez la inocencia del devenir. $^{22}$

El pensamiento de Nietzsche nos habla de una liberación, que se cumple en el eterno retorno, que desde su concepción no es sólo una idea, sino antes que nada una doctrina que nos propone una nueva vivencia del tiempo. Su aceptación nos enfrenta a un nuevo sentido creador, activo, liberador y valorizador de todo lo vivido; nos coloca ante la fórmula suprema de afirmación a la que se puede llegar en absoluto, donde la afirmación del 'instante’ vivido con plenitud juega un papel primordial, pues en la afirmación de un instante, está la afirmación del todo como inocente, ya que todos los hechos se encuentran 'encadenados', ‘trabados', 'enamorados'.

Suponiendo que dijéramos que sí en un determinado momento, con ello habríamos dicho no sólo sí a nosotros mismos, sino a toda la existencia. Porque nada existe por sí mismo, ni en nosotros ni en las cosas, y aunque sólo una vez haya vibrado y resonado nuestra alma como una cuerda por la felicidad, sería necesario toda la eternidad para construir las condiciones de este único acontecimiento, y toda la eternidad habría sido aprobada, justificada y afirmada en este único momento en que decimos 'sí'. 23

Podemos decir que en la doctrina del eterno retorno se da una redención de la voluntad que de ninguna manera es metafísica: ésta no se

${ }^{22}$ Crepúsculo de los ídolos, p. 69-70.

${ }^{23}$ F. Nietzsche, La voluntad de dominio, (1031), p. 381. 
realiza en un más allá, en un trasmundo fuera del tiempo, tampoco incluye la negación del querer, sino que la redención nietzscheana es creadora y consiste en decir 'sí' incluso al más terrible sufrimiento, a todo lo problemático de la existencia, sin culpabilizarla, ni sustraer nada de ella: decir sí a su misma repetición eterna. Mi fórmula para expresar la grandeza en el hombre es amor fati [amor al destino]: en no querer que nada sea distinto, ni el pasado, ni el futuro, ni por toda la eternidad. No sólo soportar lo necesario, y menos aún disimularlo -todo idealismo es mendacidad frente a lo necesario-, sino amarlo. ${ }^{24}$

Desde esta redención se rompe con la concepción teleológico-lineal del tiempo, pues la voluntad, bajo una nueva modalidad, puede querer hacia atrás, puede querer y transformar creativamente todo 'fue’ en un 'así lo quise'. Puede querer de un modo creador, pues el amor fati nietzscheano se traduce en un amor a lo necesario, en una aceptación gozosa de lo necesario que supera la separación entre libertad y necesidad mediante el libre sometimiento a lo necesario. Con el amor fati nos encontramos con la posibilidad de mantener una relación diferente, renovada, con lo necesario, que no se puede entender sólo como el esfuerzo de tragar la necesidad del todo, pues más bien presupone un nuevo hombre capaz de relacionarse de un modo diferente con el tiempo: que quiere su eterna repetición, y la quiere por amor a sí mismo $\mathrm{y}$ a la vida.

Les he enseñado todos mis pensamientos y deseos: pensar y reunir en unidad lo que en el hombre es fragmento y enigma y horrendo azar, -como poeta, adivinador de enigmas y redentor del azar les he enseñado a trabajar creadoramente en el porvenir y a redimir creadoramente todo lo que fue. A redimir lo pasado en el hombre y a transformar mediante su creación todo 'fue’, hasta que la voluntad diga: ‘ ¡Mas así lo quise yo! Así lo querré'. ${ }^{25}$

${ }^{24}$ Ecce homo, trad. de Andrés Sánchez Pascual, 1993, Madrid, Alianza, p. 54.

${ }^{25}$ Así Habló Zaratustra, op. cit., p. 275-6. 


\section{ANA ISABEL ILLANES}

Y aquí la necesidad no elimina al azar, no excluye el caos, sino que en el mismo devenir azaroso se da una necesidad cuya expresión es el juego; una necesidad que no es determinismo, que no representa el camino a una meta, sino simple expresión de lo existente, de la fuerza que se manifiesta como tal. Estamos ante una necesidad que, como resultado del juego del azar, es inocente.

Mientras que para la lógica mediatizadora de la moral-metafísica, -que al no lograr vivir 'instantes' capaces de ser queridos por ellos mismos, hace que el instante sólo adquiera valor en referencia a un 'deber ser'- la doctrina del eterno retorno de lo mismo se torna insoportable, nos acerca al nihilismo, a la pérdida de sentido de la existencia, de todo intento de superación. Y así se deben interpretar las palabras que lanza como dardos al oído de Zaratustra el enano, figura de pesadez: “¡Oh Zaratustra, tú piedra de la sabiduría, tú piedra de honda, tú destructor de estrellas! A ti mismo te has arrojado tan alto, -mas toda piedra arrojada- ¡tiene que caer! Condenado a ti mismo, y a tu propia lapidación: oh Zaratustra, sí, lejos has lanzado la piedra, -¡mas sobre ti caerá de nuevo!"26

De ahí que para nuestro filósofo sólo un ser transformado que se salga de los dominios metafísicos puede entender y vivir la doctrina del eterno retorno como la máxima afirmación creadora que se le puede dar a lo existente, colocándonos ante un nuevo sentido de la existencia, pues el eterno retorno no es un concepto que se pueda entender teóricamente, sino que su comprensión se encuentra ligada a niveles prácticos, de creación. Estamos ante un anuncio que propone un experimento, un cambio y una transformación radical del modo de ser del hombre: anuncia la llegada de un hombre nuevo; de un hombre no-metafísico necesariamente transformado que hace a un lado las exclusiones y distinciones establecidas por el pensamiento metafísico, que vive el tiempo de una manera angustiosa, como tensión hacia un 'deber ser', como una culminación siempre por venir.

${ }^{26}$ Ibid., p. 224. 
El eterno retorno es concebido como una disciplina, como gran pensamiento educador y seleccionador que establece jerarquías, tomando como base a la capacidad que se tiene para soportarlo. No es una doctrina selectiva entendida como la repetición que selecciona, y en su seleccionar sólo repite lo más alto, afirmativo y fuerte, pues esto implicaría caer en una moralización de lo existente, que ignora que el devenir es un vasto círculo, y todo es igualmente precioso, eterno, necesario. Es selectiva en el sentido que elige entre los que no pueden con tal afirmación, y quienes son capaces de soportar tal doctrina con fidelidad a un sólo momento de dicha que, como tal, contiene a todos los demás momentos.

La creación que Nietzsche pretende requiere de profundos cambios y transformaciones, que en Zaratustra ${ }^{27}$ van desde el hombre metafísico, el hombre del deber, de la moral-metafísica, al hombre de la libertad, para llegar a la inocencia del niño: al juego inocente del crear. La figura del niño, que es la del creador, representa al hombre liberado de la metafísica, que disfruta su propia existencia diciendo 'yo soy', sin la presión del ‘tú debes’ ni la rebelión del ‘yo quiero’. El niño es capaz de crear nuevos valores, de alcanzar la transvaloración. Con su crear se da el paso al juego del mundo en inocencia y olvido, a diferencia de los metafísicos, portadores del espíritu ascético quienes carecen de inocencia en el deseo y no aman la tierra como creadores, como engendradores gozosos del devenir.

Con el sí del niño, Nietzsche resuelve la problemática relación entre libertad y necesidad, pues el sí del niño nace de un acto de libertad, donde coinciden libertad y necesidad, donde libremente, sin resentimientos, se afirma gozosamente esa rueda que se mueve por sí misma: el eterno retorno. En este punto, tanto libertad como necesidad se encuentran bajo una nueva unidad, ya que lo que quiere la voluntad creadora es su propio destino: lo necesario, donde está incluido la caducidad corporal, tanto el dolor como el placer, todo el mal y todo el bien. Y aquí el querer de la voluntad no sólo opera como liberador,

${ }^{27}$ Ver ibid., p. 49-1. 
sino que se transforma en creador al afirmar lo necesario. El querer se convierte en creador.

Nietzsche coloca al juego como la instancia propia de esta nueva unidad creadora. Desde la mirada del juego, los contrarios se unifican para volver a disgregarse. En la productividad lúdica queda fuera toda moral-metafísica, pues en dicha productividad el hombre se siente semejante a la vida del todo, al juego del nacimiento y la muerte, donde se juega configurando y destruyendo, más allá del bien y del mal, más allá de toda estimación axiológica ya dada y fundamentada en un absoluto, en un incondicional. Pero, más que nada, en el juego del artista niño se refleja el juego originario del mundo, se refleja su dominio como voluntad de poder.

Nietzsche ve en el fenómeno dionisíaco un elemento indispensable para la comprensión del instinto creador. Dioniso es el artista creador cuyo contacto transfigura, transforma: lleva la potencia de lo falso a un grado que se efectúa no ya en la forma, sino en la transformación. La creación dionisíaca es transfiguración que no tiene que ver con la creación del Dios judeo-cristiano que crea a partir de la nada, pues Dioniso no parte de la nada, antes bien se encuentra sometido a la necesidad del eterno retorno. Y contrario a cualquier figura de la negación, este dios representa la vida afirmada en su eterno retorno, en su fecundidad y en su destrucción, donde lo transitorio, lo que pasa y muere, el mismo sufrimiento es explicado como goce de la fuerza creadora, que afirma toda la realidad, pues lo decisivo en la filosofía dionisíaca es el cambio de actitud ante el devenir, ante el fluir de las cosas, ante el sufrimiento, ante el futuro y la misma muerte: donde se comprende todo desde la caducidad del cuerpo. Por eso la muerte de Dioniso no es una objeción contra la vida, no constituye una culpabilidad, sino que su martirio y muerte son condiciones internas de la afirmación de la vida, de la sobreabundancia de ésta y de su poder re-creador. El creador es un ser que puede recrearse continuamente a partir de una pluralidad sucesiva de muertes, ya que de muchas muertes ha de estar llena la vida creadora. 
En el fenómeno dionisíaco se expresa un impulso hacia una nueva unidad que no tiene semejantes y escapa a todo pensamiento existente, que no se resuelve desde principios y fundamentos metafísicos, sino que contempla la multiplicidad, acaba con sus contraposiciones excluyentes, aprueba y santifica hasta las más terribles y enigmáticas propiedades de la vida: Dioniso con su carácter problemático, laberíntico, misterioso y sufriente como la vida misma, manifiesta ausencia de organización predeterminada y una apertura a la creación de múltiples y nuevos caminos. Aquí los contrarios no sólo se juntan, sino que proliferan y se afirman mutuamente apartándose de la uniformidad, creando una gran riqueza que posibilita la pluralidad de caminos. Estamos ante la afirmación amorosa de todo lo existente, por la desculpabilización de la realidad y la aceptación de la inocencia del devenir.

Nietzsche coloca a la creación humana como el centro de su discurso no-metafísico. En la creación artística se da la expresión gozosa de la vitalidad del juego, donde el auténtico poeta es el que crea la 'verdad', el que se orienta a la 'verdad' originaria, que no es una verdad dada de antemano, entendida como adecuación, sino una 'verdad' como error, como ilusión que hay que crear constantemente. Bajo esta óptica, la creación artística se escapa a los planteamientos substancialistas de la metafísica, pues dicha creación, no tiene el carácter de objetivación para un sujeto que se la representa, sino el carácter de la configuración apolínea, que se presenta como un triunfo precario y provisorio sobre un fondo disolvente, sobre un caos natural en incesante metamorfosis, irrepresentable por su continuo movimiento e imposibilitado de perpetuarse y constituir un yo entendido como substancia. En la individuación apolínea se da una transfiguración de las fuerzas de la naturaleza en creación artística, donde no hay mediación, sino develamiento. El ser se da como un fluir constante, sin posible fijación.

Con la palabra dionisíaco se expresa un impulso hacia la unidad, un asir lo que está más allá de la persona, de lo que es cotidiano, de la sociedad, de la realidad sobre el abismo del crimen: un desbordamiento apasionado y doloroso en estados de ánimo 
ANA ISABEL ILLANES

hoscos, plenos, vagos, una extática afirmación del carácter complejo de la vida, como de un carácter igual en todos los cambios, igualmente poderoso y feliz; la gran comunidad panteísta del gozar y del sufrir, que aprueba y santifica hasta las más terribles y enigmáticas propiedades de la vida; la eterna voluntad de creación, de fecundidad, de retorno; es sentimiento de la única necesidad de crear y destruir. ${ }^{28}$

Con su idea de arte como forma privilegiada de error, de ilusión, de mentira, como error necesario para la vida, que nos ayuda a tolerar el vivir y a soportar nuestra imposibilidad para la verdad, Nietzsche inaugura una nueva conciencia: la conciencia de la veracidad, que se cumple, no sólo con la aceptación de la condición humana de su imposibilidad para la verdad, donde el mismo valor de la vida descansa en errores creídos, sino que también se cumple con la creación humana como principal destino: Seamos veraces, tengamos la fuerza de serlo.

${ }^{28}$ La voluntad de dominio, (1049), p. 386. 